\title{
Fractal Based on Noise for Batik Coloring using Normal Gaussian Method
}

\author{
Rusmono Yulianto ${ }^{1}$, Moch. Hariadi ${ }^{2}$, and Mauridhi H. Purnomo ${ }^{3}$
}

\begin{abstract}
Noise is an un-expected signal which exists naturally at any system. In the study of fractal batik coloring, noise as a spot is generated as the basis of batik motive coloring. Even distribution of noise spots will produce art-works which involve elements of culture and technology. The development of batik motives and colors could be harmonized with the development of technology, such as the use of fractal method in order to create the new motives of batik. Fractal is a geometric form which can be separated into pieces, where each part is the repeated small version. The coloring of batik was based on the generating noise using Gaussian method. Noise on fractal batik was spots which were generated randomly on the surface of fractal batik, meanwhile Gaussian method was a noise model which followed normal distribution standard with zero average and standard deviation 1.The generating noise as coloring basis of fractal batik patterns, which was formed in the previous study, showed the distant error of noise between 9.1 pixels and 13.7 pixels. This was because the distribution of noise on the fractal batik patterns was carried out randomly using Gaussian method for every process of fractal rewriting system.
\end{abstract}

Keywords — batik fractal, noise, Gaussian, noise model

Abstrak-Derau merupakan sinyal tidak dikehendaki yang secara alamiah terdapat pada semua sistem. Pada penelitian pewarnaan batik fraktal ini, derau sengaja dibangkitkan sebagai dasar pewarnaan motif batik, sehingga dapat menghasilkan suatu karya seni yang melibatkan unsur budaya dan teknologi. Perkembangan motif dan warna batik dapat diselaraskan dengan perkembangan teknologi, diantaranya penggunaan metode fraktal dalam membangkitkan motif baru pada batik. Fraktal merupakan suatu bentuk geometris yang dapat dipisahkan ke dalam bagian-bagian, dimana masing-masing bagian itu adalah versi kecil yang berulang. Untuk pewarnaan pada batik, didasarkan pada pembangkitan derau dengan menggunakan metode Gaussian. Derau pada batik fraktal adalah titik-titik yang dibangkitkan secara random pada permukaan batik fraktal, sedangkan metode Gaussian merupakan model derau yang mengikuti distribusi normal standard dengan rata-rata nol dan standard deviasi 1. Pembangkitan derau sebagai dasar pewarnaan pola batik fraktal yang terbentuk dalam penelitian yang telah dilakukan, terdapat error jarak derau berkisar antara 9,1 piksel sampai dengan 13,7 piksel. Hal tersebut dikarenakan penyebaran derau pada pola batik fraktal dilakukan secara random Gaussian untuk setiap proses rewriting system fraktal.

Kata kunci-batik fraktal, derau, Gaussian, model derau

\section{INTRODUCTION}

B atik is our ancestors' heritage which encounters development in an artistic diversity as well as as one of two-dimensional technologies and art works with lines, colors, sizes and texture elements. Based on the previous work [1], it was found that batik had characteristics that could be symbolized into 4 approaches including:

1. Coloring symbolization (color aesthetics and technological approaches)

2. Pattern symbolization including its mythology (myth traditional and philosophical background approaches).

3. Cloth symbolization (technological comfort and cloth aesthetic material approaches), and

4. The use of batik cloth symbolization (sociological, anthropological, and traditional approaches).

The progress of batik art has touched technological advances and one of them is the study of fractal batik: Marriage of Art and Science [2]. The research discussed a

Rusmono Yulianto is with PPPPTK Seni dan Budaya, Yogyakata, 55281, Indonesia. E-mail: rusmono@elect-eng.its.ac.id, rusmono_yulianto @yahoo.com

Moch. Hariadi is with Department of Electrical Engineering, Faculty of Industry Technology, Institut Tecnology Sepuluh November, Surabaya, 60111, Indonesia. E-mail: mochar@elect-eng.its.ac.id

Mauridhi H. Purnomo is with Department of Electrical Engineering, Faculty of Industry Technology, Institut Tecnology Sepuluh November, Surabaya, 60111, Indonesia. E-mail: hery@elect-eng.its.ac.id lot about the characters of fractal owned by every batik. The character is shown by the dimension of fractal batik which has scores between 1 and 2; In the study, batik was known to always have different fractal dimension based on the origin of batik. Fractal batik is a geometric form of batik patterns which is separated into the smallest batik pattern of the whole batik patterns. The development of fractal batik is conducted using L-system. L-system method [3-4] is a method using axiom component or it is also called an initiator and production component is also known as a rewriting system. Those researches are the basis of the current work with adding noise element.

Noise is an unexpected signal which is naturally available at every system [5-6]. There are a number of researches discussing the method to eliminate noise or minimize noise, and one of them is Fractal Image de-noising [7]. Those researches discussed the use of fractal based methods to improve pictures consisting of noise, so those pictures look much better. The research has been referred in the study of fractal batik coloring. In the coloring of fractal batik, the writers neither reduced nor eliminated noise and in fact, noise is proportionally generated as the basis of coloring. In order to generate noise, Gaussian method was used [8].

Noise on fractal batik is spots which are generated randomly on the surface of batik, hence it will form like even spot distribution on the surface of batik pattern. The generation of noise on fractal batik using Gaussian method [9] is expected to become the basis of the creation of batik 
art work diversity; therefore, it can enrich the Indonesian batik collection.

The technique randomly distributed color when given fractal dimension, color features are formed. While these color features when developed, forming a diverse motif. What is important in this regard: color features that form a motif that various. This technique improves existing ones: before making fractal pattern with a line, while this study makes a fractal pattern using color features are generated randomly.

\section{METHOD}

\section{A. Noise as Basic Coloring on Fractal Batik}

\section{Batik}

In general, the process of making batik through three stages of the staining, the granting of the night (candle) wax on the of cloth and the release the of cloth. White cloth will be colored according to taste our basic white or fixed before then in the given night. The process of providing this evening to use the process of batik with canting hand or with the cap. On the night the cloth was given to the batik dyeing process can't be get as it is covered by the night (wax resist). After a given night, the water that has entered batik colors. This coloring process can be done several times as you wish how many colors you want. If the process of coloring, and the night finished the evening with the warming process. Batik has become a melting braised till night, and regardless of the water. Boiling water is done twice, the last with a chemical solution to turn off the color of the stick on batik. After boiling is complete, batik immersed in cold water and dried.

Based on the publication "Batik, The Impact of Time and Environment [10], there are at least three stages of batik ornamentation, namely:

1. Klowongan; a process of drawing and formating the basic element.

2. Isen-isen; process of filling parts of the ornament from determined sen pattern, such as motives of cecek, sawut, cecek sawut, sisik melik, and so on.

3. Harmonious ornamentation; the placement of any background of the entire design hence it shows general harmonization, such as sekar sedhah, rembyang, sekar pacar and so on.

\section{Fractal}

Fractal is a geometric form which can be separated into pieces where each piece is the small version of the global version [11-12]. For example, a stem of tree with many branches and twigs.

Geometry of fractal has important characters such as self similar, self affine, self inverse and self squaring(the scale of lenght is not specific or invariant). Therefore, fractal batik is a geometric form of a batik pattern which can be separated into the smallest batik patterns of the global pattern.

\section{L-System}

An L-system or Lindenmayer system is a parallel rewriting system, namely a variant of a formal grammar, most famously used to model the growth processes of plant development, but also able to model the morphology of a variety of organisms. L-system consists of an alphabet of symbols that can be used to make strings, a collection of production rules which expand each symbol into some larger string of symbols, an initial "axiom" string from which to begin construction, and a mechanism for translating the generated strings into geometric structures. L-systems can also be used to generate self-similar fractals such as iterated function systems. L-systems were introduced and developed in 1968 by the Hungarian theoretical biologist and botanist from the University of Utrecht, Aristid Lindenmayer (1925-1989).

L-system is method which is used to construct fractal batik Components of an L-system are as follows [2-3]:

- Axiom also called an initiator; a string indicating earlier string or initial string.

- Production; production or rewriting system rule.

Rewriting system rule for cell growth has system that every string $A$ will be replaced by string $A B$, meanwhile, every string will be replaced by string A. For example:

Variable A B

Axiom: A

Rewriting system rule: $(\mathrm{A} \rightarrow \mathrm{AB}),(\mathrm{B} \rightarrow \mathrm{A})$. The result is as follows:

$\mathrm{n}=0: \mathrm{A}$

$\mathrm{n}=1: \mathrm{AB}$

$\mathrm{n}=2: \mathrm{ABA}$

$\mathrm{n}=3: \mathrm{ABAAB}$

$\mathrm{n}=4:$ ABAABABA

$\mathrm{n}=5$ : $\mathrm{ABAABABAABAAB}$

n=6: ABAABABAABAABABAABABA

$n=7: A B A A B A B A A B A A B A B A A B A B A$

ABAABABAABAAB

\section{Noise}

Noise is an un-expected signal which naturally exists at any system. Source of noise can be grouped into 3 categories [5-6]: Source of intrinsic noise appears from random fluctuation inside a physical system such as thermal and shot noise. Man-made source of noise such as motor, switch, digital electronic, noise is caused by natural disturbances such as lightening and sun-spots.

5. Noise on Fractal Batik

Generating noise on fractal batik is the coloring basis of fractal batik , and this could be done by distributing spots randomly on the surface of fractal batik. Process of generating noise on fractal batik used Gaussian method. Block diagram of noise generation as the basis of coloring fractal batik can be seen in Figure 2.

The formation of fractal batik was based on basic ornament of batik, consisting of klowongan, isen-isen and harmony. Those ornaments were then modeled in the fractal batik using L-system hence motives very similar to the original batik could be obtained or new motives were created. Motives obtained from fractal batik were then given noise which was generated randomly on the surface of batik using Gaussian method. The obtained results appeared as fractal batik with spots spreading evenly on the surface of fractal batik.

\section{B. Generating Fractal}

Generating noise on the fractal batik using Gaussian method is the basis of coloring which will be carried out on the next study. The process of generating noise on fractal batik can be seen in Figure 2, where earlier step of the research is to construct fractal batik using L-system based on ornaments of batik such as isen-isen, kelowongan and harmony. 


\section{Fractal Batik using L-system}

Fractal batik is a geometric form of a batik pattern which can be separated into the smallest patterns of batik from the global pattern of batik. The development of fractal batik was carried out using L-system method that was a method with axiom component also known as initiator. Axiom component caused the earlier growth of fractal batik formed, this was done in repeated order because L-system also had production component, which can be said as a rewriting system.

Block diagram on the stages of constructing fractal batik using L-system method is represented as follows in Figure 3. Fractal can be grouped_on the basis of self-similarity concept [11] namely:

a. Exact self-similarity

This was the strongest kind of self-similarity. The fractal looked similar in various or different scales and it was determined by iteration system function which performs exact self-similarity.

b. Quasi- self-similarity

It was a lose form of self similarity. The fractal looked as if it were the same or identical in different scales and consisted of small copies of all fractals which were diverted. The form was also declining, Recurrence fractal usually uses quasi-self-similarity

c. Statistical-self-similarity

This was the weakest type of self similarity. The fractal had quantitative measurement or maintained statistics in its different scales. Random fractal is the example of statistical-self-similarity, however, not all self-similarity objects are fractal, e.g. Euclidian lines

2. Gaussian Normal Method for Noise Generation on Fractal Batik

Noise which was generated on fractal batik was the basis of coloring which will be discussed in further research. Noise functioned to give random spot distribution on the surface of fractal batik. To generate noise, Gaussian method was performed.

Gaussian method as noise distribution is a noise model which follows normal standard distribution with mean $=0$ and standard deviation $=1$. The effect of noise on color distribution was shown by the emergence of colored spots in which the number of spots was equal to the percentage of noise. The basic formula used for noise generation is as Equation 1.

$f\left(x \mid \mu, \sigma=\frac{1}{\sigma \sqrt{2 \pi}} e^{\frac{-(x-\mu)^{2}}{2 \sigma^{2}}}\right.$

The Equation 1 is the formula of normal Gaussian method which is resulty a model as figure 5 , with:

$\mu=$ mean

$\sigma=$ standard deviation

Based on the formula of $f(\mathrm{x} \mid \mu, \sigma)$, steps for generating noise are as follows.

a. Develop random numbers $[0,1]$ using Gaussian distribution

b. for noise applied spots, the image function value was added by the available noise, or formulated as Equation 2.

$y(i, j)=x(i, j)+p . a$

where,

$a \quad=$ random numbers with Gaussian distribution

$p \quad=$ noise percentage

$y(i, j)=$ noise applied image value $x(i, j) \quad=$ image figure prior to noise application

Random function could not be used directly to generate Gaussian distributing random numbers. Modeling was required to convert random number distribution into certain $\mathrm{f}$ function as like as in figure 6. The modeling used was Gaussian Mixture Model (which was formed by combining multivariate normal density components consisting of means, covariance, and mixture proportion using Gaussian mixture (gm distriptio) as a constructor.

$\mathrm{MU}=[12 ;-3-5] ;$ \% Means

SIGMA $=\operatorname{cat}\left(3,[2 \quad 0 ; 0.5],\left[\begin{array}{lll}1 & 0 ; 0 & 1\end{array}\right]\right) ; \%$

Covariances

$\mathrm{p}=$ ones $(1,2) / 2 ;$ \% Mixing proportions

obj = gmdistribution (MU, SIGMA, p);

where,

MU = mean

SIGMA = covariances

$\mathrm{P} \quad=$ mixture proportions

Figure 7 shows the result of noise development using Gaussian mixture model. Generating noise in Figure 7 was performed with no fractal component. Moreover, in order that the noise could be put into fractal batik, MU (means) components of noise modeling were initialized fractal (init the turtle graphic) which enabled noise to follow the formed fractal pattern.

\section{RESULTS AND DISCUSSION}

Fractal on batik is an interesting research topic since it discusses the development of batik which is one of Indonesian art works. In the later development, batik has been created using technology called fractal which enrich batik motives and colors.

In this research is to provide more background research that has established a pattern. There is a method of Gaussian incorporation with fractal methods. This research discussed more on the basis of fractal batik coloring generated by noise using Gaussian method. This research continued the previous research (2) on "Fractal Batik": Marriage of Art and Science, which discussed fractal characters of batik dimensions which scored between 1 and 2. Batik always has different fractal dimensions depending on batik's place of origin.

\section{A. The Result of Fractal without Noise.}

Fractal is a geometric form which can be separated into parts in which each part is the small versions of the entire version [10]. Meanwhile, fractal batik was a fractal in a batik pattern which was created using a method called $L$ system or Lindenmayer system which works like mathematic theory on the growth of plant. The components of L-system could not be separated from axiom and production. The result of fractal without Noise.

Figure 8 a fractal batik pattern without noise as the basis of coloring. This pattern was developed using the following F axiom:

ostarting seed

axiom = ' $\mathrm{F}$ ' ;

and rewriting system

rule (1). before $=$ ' $\mathrm{F}^{\prime}$;

rule (1). after $=$ 'F-F-FF+FF' ;

The rule of rewriting system will produce patterns. Therefore, the rule used was important to form fractal batik patterns. Even with the rule following certain original traditional batik patterns will produce the same fractal batik patterns as the original ones. 
In addition to rule. the rewriting system process required rotation angle which functioned to form fractal pattern rotation. Figure 8 shows fractal rotation angle.

oangle: +operator means turn left; -

operator means turn right

delta $=90 ; \%$ degrees

delta $=60 ;$ odegrees

The fractal growth which produced batik pattern as shown in Figure 8 was the result of rewriting system process added by iteration. This can be seen in figure 9 . The number of fractal growth.

Fractal growth began from the first iteration when the rewriting system process had fractal growth $=0$. This process continued until it reached the expected iteration. So, the more the iteration was used, the more the fractal growth was, as a result, the graph of the number of fractal growth inclined.

\section{B. The Result of Fractal with Noise}

A simple batik pattern produced by the fractal shown in Figure 8 was then developed by giving noise as coloring basis. The noise which was put into the formed fractal was generated using Gaussian method. The result can be seen in Figure 10 The result of fractal with coloring basis.

Generating noise was performed every rewriting system process of fractal lines following the formed fractal batik pattern lines. Figure 10 shows noise with yellow coloring basis and blue fractal batik pattern lines.

Figure 10 also shows the generated noise lied outside and inside fractal batik pattern lines, as a result, it looked that the noise distributed unevenly, and some lines were even covered by noise. This was because generating noise was performed by random Gaussian.

\section{Noise Distant Error}

Noise which had uneven distribution to fractal batik lines was considered as an error. In Figure 10, noise error is symbolized as green colored pixel, mean while fractal line as red color.

Noise produced Error against fractal lines could be measured by calculating the distance between the colored pixel and the fractal lines.

Distant Error $=$ colored pixel - fractal line

The closer the colored pixel against the lines was, the smaller the distant error of noise was. Meanwhile, the farther the colored pixel against the line was, the bigger the distant error of noise was. This can be seen in Figure 11.

Figure 11 is the graph on distant error of pixel against fractal lines. Spots A, B, C, D and E are the spots of colored pixel which were measured their noise distant error against the fractal lines with the following values: $A=10, B$ $=13.7, \mathrm{C}=10.8, \mathrm{D}=10.6$ and $\mathrm{E}=9.1$

Based on the above values, it was found that the farther the colored pixel spots against the fractal lines were, the bigger the distant error of noise was. Meanwhile, the biggest distant error laid on the pixel spot B with the distance of 13.7 pixel while the smallest one was on the pixel spot E with the distance of 9.1 pixel.

The measurement of noise distant error shown by the graph in Figure 11 was performed against the last fractal (it is shown by red fractal lines in Figure 10). The result would be different if the measurement was conducted by the other fractal lines because generating noise as the basis of coloring of fractal batik was carried out using random Gaussian for every fractal rewriting system process.

The impact from errors:

The more distant noise from the fractal line, it will form the instability or lack of rules on the staining pattern in the desired form, while getting closer noise to the line the fractal, the stability of the staining will form a fine batik pattern

As for how to overcome them :

Analyze the stability by determining the variables and parameters of Distribution Normal is

a. Random variables (variables that have a value of the count)

b. Continuous variables (random variable having the value of having a certain interval)

c. Mean (location parameter)

d. Deviation (The scale parameter)

\section{CONCLUSION}

The analyse is written in the section III, it has achieved these conclusion:

1. Fractal was a method which could be used to create different kinds of batik motives rapidly.

2. Batik patterns using fractal could be formed due to rule $=$ 'F-F-FF+FFF' and axiom = ' $\mathrm{F}$ ' during the rewriting system process; therefore, it is possible to create various batik patterns by using different rules.

3. Generating noise as the basis of fractal batik coloring had uneven distribution because noise generation was conducted using random Gaussian with an average standard value of 0 and standard deviation of 1 .

4. The uneven noise distribution on the patterns of fractal batik was considered an error which could be measured by calculating the distance between the colored pixel and the fractal lines in which in this study the error was around 9.1 pixel until 13.7 pixel.

5. The measurement of noise distant error was conducted every fractal line of the formed fractal batik patterns. This is because generating noise was performed randomly on every fractal rewriting system process. 


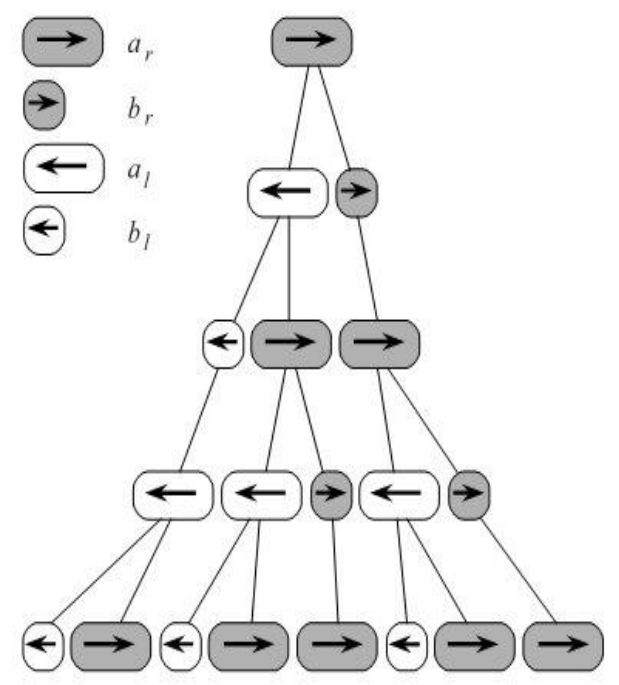

Figure 1. Simulation of filament breakdown (anabaenacatenula) using DOL-system)

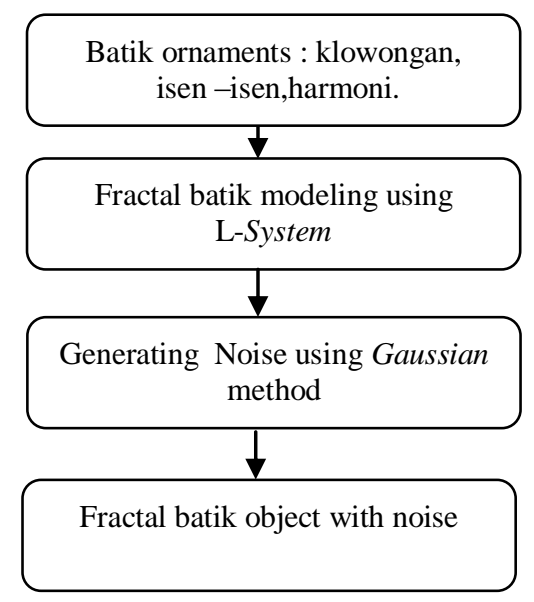

Figure 2. Block diagram of generating noise on fractal batik

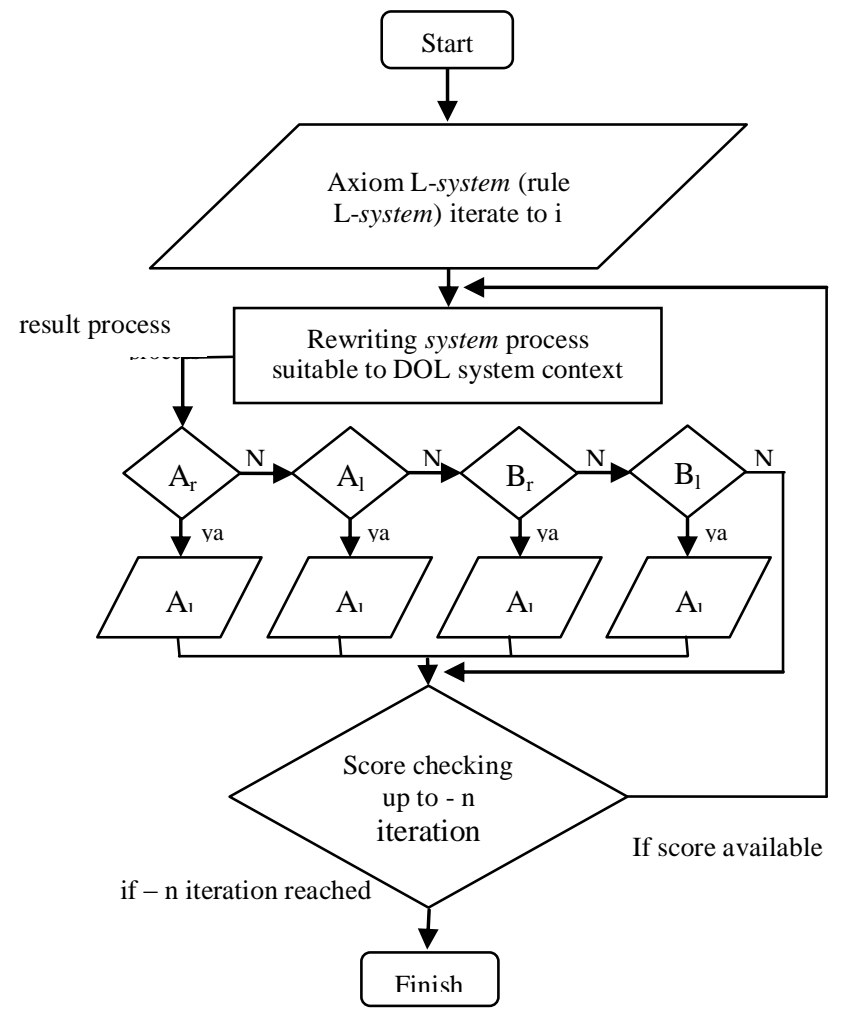

Figure 4. Flowchart fractal using L-system

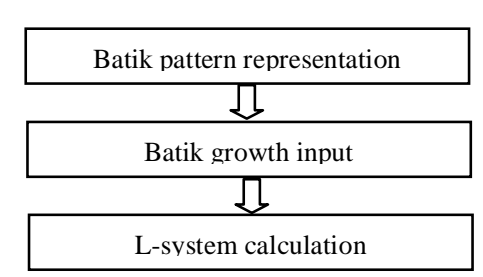

Figure 3. Block diagram of the stages of constructing fractal batik using L-system

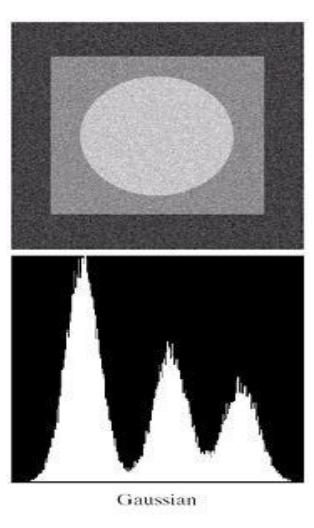

Figure 5. Gaussian noise 


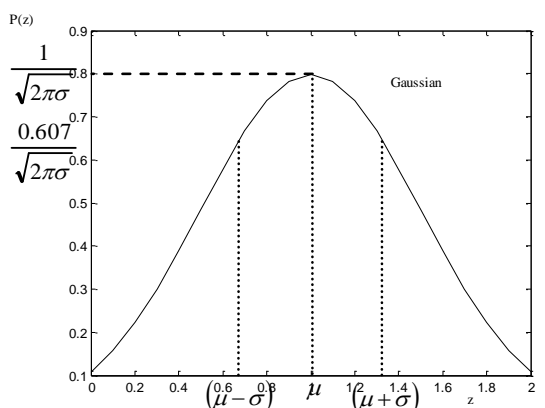

(a)

$\stackrel{\mathrm{P}(2)}{\mathrm{K}}$
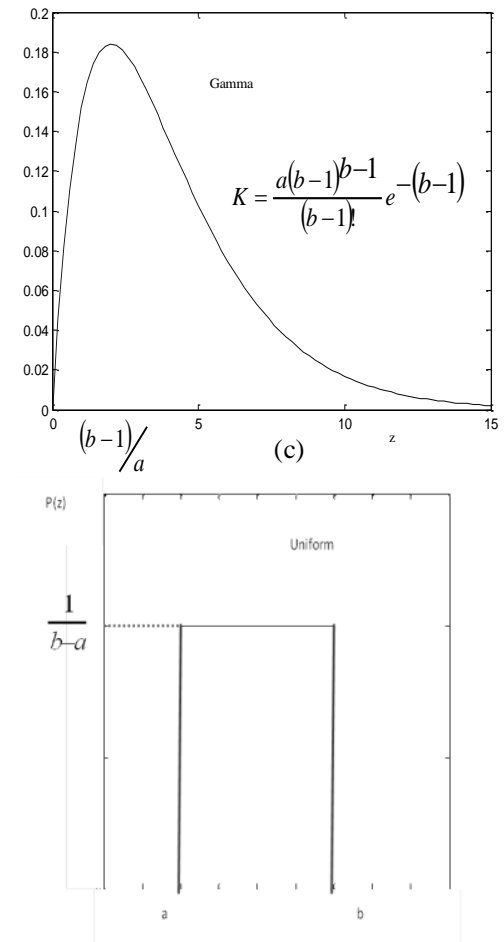

(e)

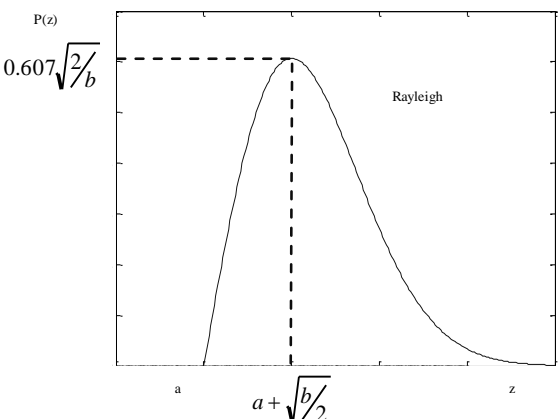

(b)

$\mathrm{P}(\mathrm{z})$

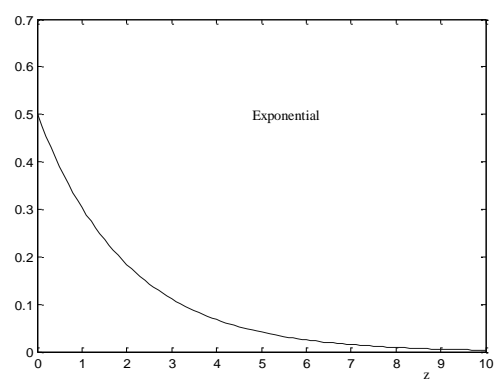

(d)

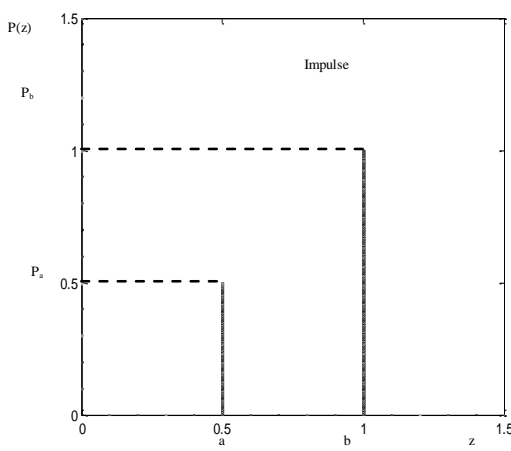

(f)

Figure 6. PDF of Gaussian random variable z (a) Gaussian,(b) Rayleigh,(c) Gamma,(d) Exponential,(e) Uniform,(f) Impulse

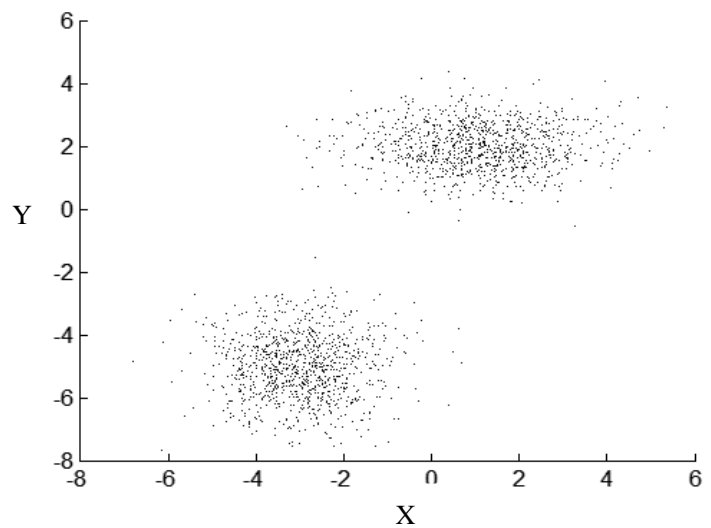

Figure 7. Noise development with no fractal
The Result of Fractal without Noise

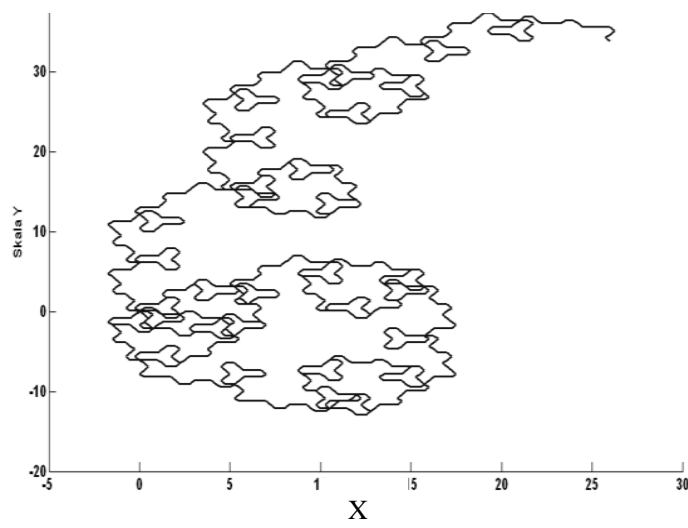

Figure 8 . The result of fractal 


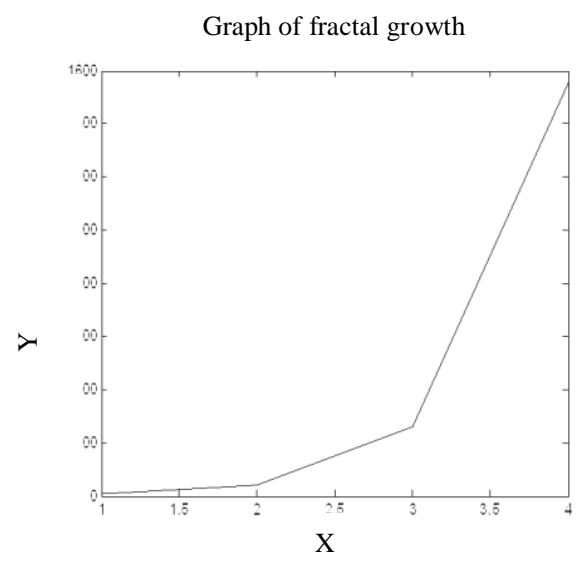

Figure 9. The number of fractal growth

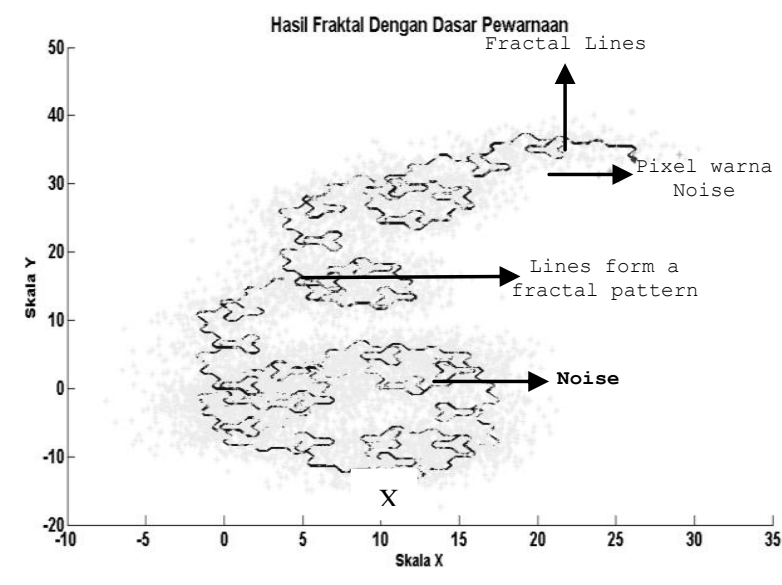

Figure 10. The result of fractal with noise

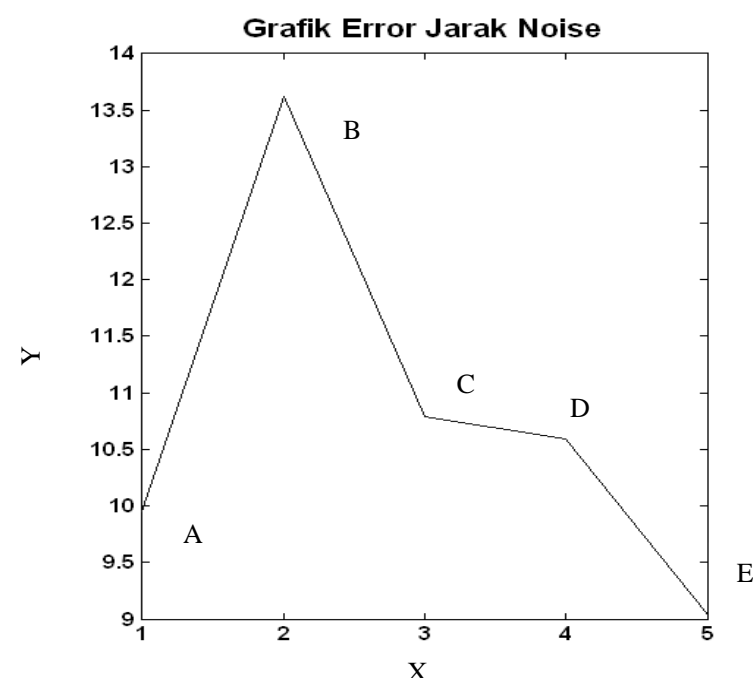

Figure 11. Noise distant error graph

\section{REFERENCES}

[1] Y. Efendy."Seni Kriya Batik Dalam Tradisi Baru Menghadapi Arus Budaya Global." Jurnal Seni Rupa dan Desain Volume 1,yang diterbitkan oleh Pusat Penelitian dan Pengembangan Masyarakat (P3M) Sekolah Tinggi Seni Rupa dan Desain Indonesia (STISI) Bandung, 1 Agustus 2000.

[2] Y. Hariadi, Fractal Geometry on Batik.Journal of Social Complexity. Bandung Fe Institute, 2008.

[3] W.Constantine and D. Percival, "Insightful Fractal Time Series Modelling And Analysis", 19 April 2010.

[4] P. Prusinkiewicz, M. Shirmohammadi, and F. Samavati, "Lsystems in Geometric Modeling", Proceedings of the Twelfth Annual Worskshop on Descriptional Complexity of Formal Systems, pp. 3-12, 2010.

[5] J. Knutzen, "Generating Climbing Plants Using L-Systems", Master of Science Thesis in the Programme Software Engineering andTechnology Department of Computer Science and Engineering Chalmers University Of Technology University Of Go Thenburg, Göteborg, Sweden, March 2009.

[6] O. Št'ava , B. Beneš , R. Moch , D. G. Aliaga and P. Krištof : Inverse Procedural Modeling by Automatic Generation of Lsystems, 2010.
[7] M. Ghazel, G. H. Freeman, and E. R. Vrscay,'Fractal Image Denoising", IEEE Transactions On Image Processing, Vol. 12, No. 12, Desember 2003.

[8] M. Bicego, D.Gonzalez-Jimenez, E.Grosso, J. L. A. Castro. "Generalized Gaussian Distribution for Sequential Data Classification”, Proc. IEEE Int. Conf., 2008.

[9] D. Pastor, A. Amehraye, "Algorithms and Applications for Estimating the Standard Deviation of AWGN when Observations are not Signal-Free", Journal Of Computers, Vol. 2, No. 7, September 2007.

[10] H. S. Doellah. "Batik : The Impact of Time and Environment", Published by Danar Hadi, 2002.

[11] W. Wardiana and A. Heryana,"Studi Komparasi untuk Unjuk Kerja Komputer pada Proses Perhitungan Fractal", Pusat Penelitian Informatika-LIPI Bandung, Jurnal Teknologi Industri Vol. XII No.1 Januari 2008: 63 - 70.

[12] J. Jauhari, "Pengembangan Perangkat Lunak Pembangkit Geometri Fraktal Berbasis Bilangan Komplek (PLFrakom)", Fakultas Ilmu Komputer, Universitas Sriwijaya, Jurnal Generic, Januari 2010. 